\title{
THE EFFECTIVENESS OF BILINGUAL THEMATIC MODULE BASED TOWARD STUDENTS LEARNING ACHIEVMENT
}

\author{
Ina Rohiyatussakinah ${ }^{1}{ }^{1}$ Nurhidayanti ${ }^{2}$ \\ Universitas Banten Jaya \\ inasakinah1987@gmail.com \\ yantimath15@gmail.com
}

\begin{abstract}
Thematic learning is being promoted where in one learning is interrelated. The purpose of this study is first, to find out how much students respond to the use of bilingual modules in thematic learning, and to find out how much thematic learning achievement using bilingual modules. This research was conducted at SDIT Widya Cendekia, Serang, Banten, using quantitative writers. The writers used a bilingual module on thematic learning therefore students were more interested and easier to learn. The activities of students who pay attention to the lessons explained by the teacher was still a few, therefore the subject matter delivered is poorly understood by students. Used of bilingual modules is one alternative that can be used thematic concepts it could be better understood by students. Learning media is used a bilingual module. In general students stated that they agreed to learn thematic using bilingual modules in class. This can be seen from the student response seen from the results of the questionnaire that as many as $77.1 \%$ of students gave a high response and $22.9 \%$ of students gave a low response. This means that bilingual modules are very effective in learning and their achievement.
\end{abstract}

\section{Keywords: Effectiveness, Module, Bilingual, Achievement}

\section{INTRODUCTION}

Based on Piaget theory about how human develop and make sense of their world. From Piaget perspective human are always striving to make a sense of their environment, their biological maturation, their interaction with environment, and their social experience combine to influence how they think about things. Learning is the effort of student to get information, knowledge, skill and new challenging as their experience in environment interaction. The change of education can be seen from higher competency in their real life situation. According to Piaget, as children grow and mature, they pass through four stage of cognitive development: sensor motor, preoperational, concrete operational, formal operational. Younger children deal with their world in more concrete.

Piaget Stage of Cognitive Development 


\begin{tabular}{|c|c|c|}
\hline Stage & Age & $\begin{array}{l}\text { Kinds of } \\
\text { Thinking } \\
\text { Abilities }\end{array}$ \\
\hline Sensorimotor & $\begin{array}{l}\text { birth-2 } \\
\text { years }\end{array}$ & $\begin{array}{l}\text { Begin to } \\
\text { recognize, } \\
\text { can imitate }\end{array}$ \\
\hline Preoperational & $\begin{array}{l}2-7 \\
\text { year }\end{array}$ & $\begin{array}{l}\text { Develops use } \\
\text { of language, } \\
\text { begin ability } \\
\text { to think } \\
\text { symbolically; } \\
\text { can see } \\
\text { another } \\
\text { person's } \\
\text { point of view } \\
\text {, lack logical } \\
\text { mental } \\
\text { operation at } \\
\text { this stage }\end{array}$ \\
\hline $\begin{array}{l}\text { Concrete } \\
\text { operational }\end{array}$ & $\begin{array}{l}7-11 \\
\text { year }\end{array}$ & $\begin{array}{l}\text { can solve } \\
\text { concrete } \\
\text { problem in } \\
\text { logical } \\
\text { fashion, able } \\
\text { to classify }\end{array}$ \\
\hline $\begin{array}{l}\text { Formal } \\
\text { operational }\end{array}$ & $\begin{array}{l}11- \\
15 / \text { adult }\end{array}$ & $\begin{array}{l}\text { can solve } \\
\text { abstract } \\
\text { problems in } \\
\text { logical } \\
\text { fashion, has } \\
\text { concern for } \\
\text { social issues }\end{array}$ \\
\hline
\end{tabular}

In this case the children on concrete operational (7-11) can solve concrete problem in logical fashion, able to classify. Here they are able to use bilingual to understand what the communication from L1 or L2. Children can apply language in this situation from natural situation rather than classroom situation.
According to ( Madrid and Huges, 2011; 20-28) Bilingualism used Balanced Theory it represents two languages coexisting in equilibrium, the second languages increases at expense of the first. It can be seen from the theory balance with L1 and L2. It symbolic from upper floor and balanced bilinguals, it describes the relationship between cognition and the level of bilingualism. The closer students are to being bilingual, the greater the chance they have of obtaining cognitive advantages.

Bilingual in education program have the objective of the bilingual programmed is the integration of students in the monolingual community. The students are submersed in the foreign language from the beginning (or after some form of transitory bilingual instruction). It have the advantages of applying in bilingual education they have positive relationship between bilingual individuals and thought process, organization skill, reasoning and visual and spatial skills. For all competences in subject taught in L2 are similar to those acquire in L1 and there are no significant differences. Beside that the level of knowledge in L1 has a strong influence in the result obtain in L2 instruction, in school subject matter such as math and English, is Being balance of 
them in daily learning. Student learn math using bilingual in their daily conversation. Bilingual applied can be motivation and commitment for students in learning second language, for improving their English skill as general in L1 development, as positive family, social, and cultural environment. Teaching the subject helps consolidate a writer knowledge of the field making one responsible to fill in gaps not previously investigates.

Therefore, the children apply communication in the classroom by using bilingual module in thematic learning. The module interact them using target language and improve their communicative skill to learning achievement and motivation to improve their ability.

\section{METHODOLOGY}

$\begin{array}{rrr}\text { This } & \text { research } & \text { applied } \\ \text { quantitative } & \text { Research } & \text { method. }\end{array}$
According to Creswell (2009:1) "Quantitative writers is a means for testing objective theories by examining the relationship among variables. These variables can be measured, typically on instruments; therefore numbered data can be analyzed using statistical procedures. The final written report has a set structure consisting of introduction, literature and theory, methods, results, and discussion."
This study tries to describe the effectiveness of using bilingual module. The writers design is. Therefore, the design was called a pre-test and post-test control class design.

The study design is adopted from Ary, et.al (2002: 308).

Table 3.1 Randomized class, pre-test and post-test

\begin{tabular}{cccc}
\hline Class & $\begin{array}{c}\text { Pre- } \\
\text { test }\end{array}$ & $\begin{array}{c}\text { Independent } \\
\text { variable }\end{array}$ & $\begin{array}{c}\text { Post- } \\
\text { test }\end{array}$ \\
\hline $\mathrm{E}$ & $\mathrm{Y}_{1}$ & $\mathrm{X}$ & $\mathrm{Y}_{2}$ \\
$\mathrm{C}$ & $\mathrm{Y}_{1}$ & - & $\mathrm{Y}_{2}$
\end{tabular}

Notes :

$\mathrm{E}=$ experimental class

$\mathrm{C}=$ control class

$\mathrm{Y} 1=$ pre-test

$\mathrm{X}=$ treatment on the experiment class

$\mathrm{Y} 2$ = post-test

This writers design was present several characteristics;

1) It has two class of experimental subjects or treatment class and control group;

2) The two class compared with respect two measurements of observation on the dependent variable;

3) Both class was be measured twice, the first measurement serve as the pre-test and the second as the post-test; 
4) Measurement on the dependent variable for both class was be done at the same time with the same test; and

5) The experimental class manipulated with particular treatment.

The study design is adopted from Ary, et.al (2002: 308).

Table 3.1 Randomized class, pre-test and post-test

\begin{tabular}{cccc}
\hline Class & $\begin{array}{c}\text { Pre- } \\
\text { test }\end{array}$ & $\begin{array}{c}\text { Independe } \\
\text { nt variable }\end{array}$ & $\begin{array}{c}\text { Post- } \\
\text { test }\end{array}$ \\
E & $\mathrm{Y}_{1}$ & $\mathrm{X}$ & $\mathrm{Y}_{2}$ \\
$\mathrm{C}$ & $\mathrm{Y}_{1}$ & - & $\mathrm{Y}_{2}$
\end{tabular}

Notes :

$\mathrm{E}=$ experimental class

$\mathrm{C}=$ control class

$\mathrm{Y} 1$ = pre-test

$\mathrm{X}=$ treatment on the experiment class

$\mathrm{Y} 2$ = post-test

These writers used linear regression to investigate effectiveness of using bilingual module in thematic learning. Hence, linear regression is regression analysis which is used to learn the functional relationship between the variables. Therefore, linear regression is appropriate to be used to test the causal relationship between two variables. Basically, linear regression is different with linear correlation; linear correlation is used to test between the relationship of two variables and the degree of variable $\mathrm{X}$ and $\mathrm{Y}$ can be changed their position or it can be said it is a vice versa relationship.

While the linear regression, the degree of the variables $\mathrm{X}$ and $\mathrm{Y}$ cannot be changed or it can be said it is a causal relationship. Furthermore, this study used F-test to test the hypothesis. F-test is used to examine the influence of independent variable and dependent variable. After getting the data, the writer analyzed data through quantitative analysis and statistical procedure. The data comes from the result of pre-test and post-test analyzed by using t-test application.

To find out homogeneity of variances, the formula of Levene's test from SPSS version 16 programs for window in this writers. The steps are:

a. Setting the null hypothesis $\left(\mathrm{H}_{0}\right)$

b. Setting the level of significant at $(0,05)$

c. Analyzing the homogeneity of variances by using Levene's test from the SPSS version 16.0 program for window.

If the asymptotic significance $(0,05)$, the null hypothesis is accept which means the scores of experimental and control class are homogeneous. In contrast, if asymptotic (p) is less than the level of 
significance (0.05), the null hypothesis is reject which means the scores of experimental class were not homogenous.

\section{RESULT AND DISCUSSION}

The data were collected in four meetings of the writers. The Pre-test was given to the both of the class at the first meeting of the writers. Then the writers did the treatment twice in experimental class. Finally, the post-test was given at the last meeting of the writers.

\section{Table I}

The Result of Tests at Experimental and Control Class

\begin{tabular}{|c|c|c|c|}
\hline \multicolumn{2}{|c|}{ Experimental Class } & \multicolumn{2}{|c|}{ Control Class } \\
\hline Pre Test & Post & Pre Test & Post \\
& Test & & Test \\
& & & \\
\hline $1225=6$ & $1205=$ & $1205=6$ & $1355=6$ \\
2.75 & 74.5 & 0.25 & 7.75 \\
& & & \\
\hline
\end{tabular}

Table 1 show the result of experimental and control class. The score experimental group increased into 11.75 point and shows that the highest score of Post-test 74.5 and the Pre-test lowest score of experimental is 62.75. in control group the result increased into 7.5 point and the highest score of Post-test 67.75 and the Pre-test lowest score of is 60.25. The improvement can be seen in the following chart.

Figure I

\section{Experimental Class}

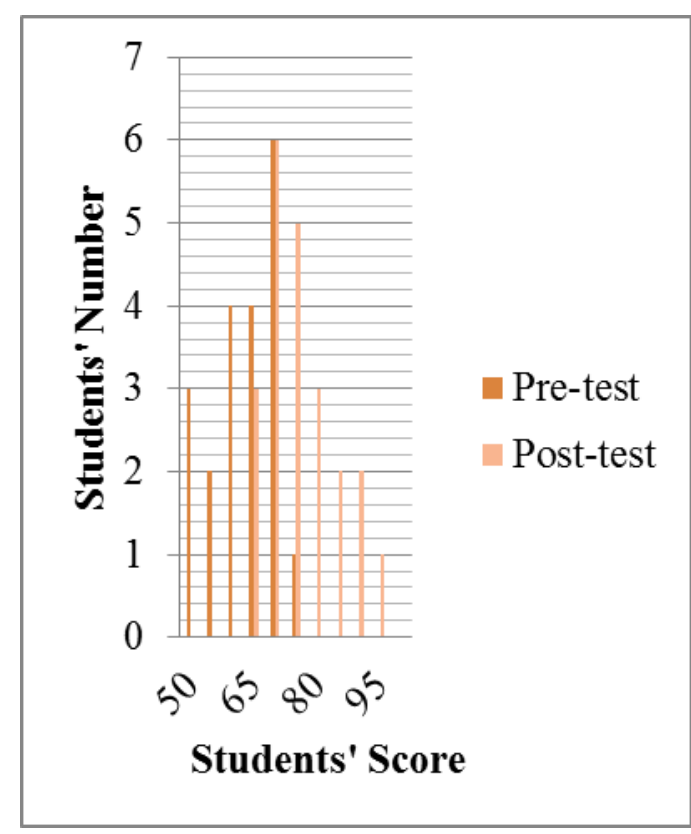

Figure 2

Control Class

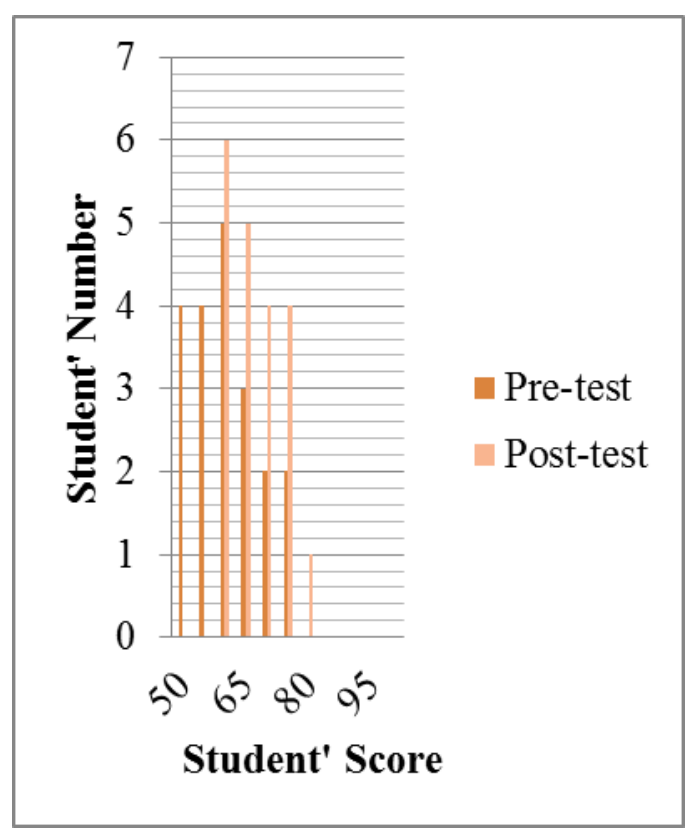


Both of the chart above shows that there are the different result of pre-test and post-test between control class which did not get treatment and the experimental class which got treatment after pre-test. The result of pre-test in experimental class shows the highest score is 75 for 1 student and the lowest score is 50 for 3 students. Then, the result of post-test shows that the highest score is 90 and the lowest score is 65. While, the result of post-test in control class shows that the highest score was 80 and the lowest score were 60 .

From both of chart above, it was assumed that there was the improvement in both of control and experimental class. But, in Experimental class the score is higher than the control class. It means that the ability of experimental class is better than the control class after getting treatment.

\section{Result}

To know the test whether are valid or not for control and experimental group, the writer used Pearson Product Moment formula and $\mathrm{t}_{\text {count }}$ formula. The scores were calculated (see appendix 3). The result of validity of the test: pre-test is 2.145 and post-test is 2.671 in control class. Then in experimental class, pre-test is 2.735 and post-test is 2.842 .
Table 2

The Result of the Validity of the Tests at Experimental Class and Control Class

\begin{tabular}{ccc}
\hline Class & $\begin{array}{c}\text { Pre- } \\
\text { test }\end{array}$ & $\begin{array}{c}\text { Post- } \\
\text { test }\end{array}$ \\
\hline Experimental & 2.735 & 2.842 \\
Control & 2.145 & 2.671
\end{tabular}

Based on the result, the writers has obtained that $\mathrm{t}_{\text {count }}$ are higher that $\mathrm{t}_{\text {table }}$. The distribution of $\mathrm{t}_{\text {table }}$ for 37 Students and for $\alpha=0.05$ is 1.734 . Thus, the writers assumed that test in control and experimental Class is valid.

\section{Reliability of the Test}

To know the test whether was reliable or not for control and experimental class, the writer used Pearson Product Moment formula and Spearman brown formula. The scores were calculated (see appendix 3). The result of reliability of the test : Pre-test is 0.621 and post-test is 0.695 in control class. Then in experimental class, pre-test is 0.658 and post-test is 0.715 . 
Table3

The Result of the Validity of the Tests at Experimental Class and Control Class

\begin{tabular}{ccc}
\hline Class & Pre-test & $\begin{array}{c}\text { Post- } \\
\text { test }\end{array}$ \\
\hline Experimental & 0.658 & 0.715 \\
Control & 0.621 & 0.695
\end{tabular}

Having the writer consulted it whit $\mathrm{r}_{\text {table }}$ value of product moment with $\mathrm{N} 20$, significance is $5 \%$. The writer has obtained that $\mathrm{r}_{11}$ is higher than $\mathrm{r}_{\text {table }}$. The distribution of $\mathrm{r}_{\text {table }}$ for 20 students and for level significance $5 \%$ is 0.444 thus the result of control and experimental class is reliable.

\section{Test of Analysis Requirement}

\section{Test of Normality}

The writer used Chi square to measure the data normally. Based on the result of the calculation, the result of data normality of the test : pre-test in control class is $3.144 \leq 9.488$ and in experimental class is $6.356 \leq 9.488$. And for the post-test in control class is $3.246 \leq 9.488$ and in experimental class is $6.593 \leq 9.488$ Therefore, it can be concluded that the data of pre-test and post-test shows that the distributions of both class were normal.
Table 4

The Result of the Validity of the Tests at Experimental Class and Control Class

\begin{tabular}{ccc}
\hline Class & $\begin{array}{c}\text { Pre- } \\
\text { test }\end{array}$ & $\begin{array}{c}\text { Post- } \\
\text { test }\end{array}$ \\
\hline Experimental & 6.356 & 6.593 \\
Control & 3.144 & 3.246
\end{tabular}

\section{Test of Homogeneity}

The result of data sample homogeneity of the test; Pre-post test in control and experimental class of two variants by comparing the value of the highest variant and the lowest variant with significance level 0.05 for $\mathrm{df}=19$ is 4.38 . The significance value of pre-test data can be concluded that in both of class, control class and experimental class, $\mathrm{f}_{\text {count }} \leq \mathrm{f}_{\text {table }}$ or $1.687 \leq 4.38$. And the result of post-test is $1.402 \leq 4.38$. Therefore, the variances of two variable were in both class were homogeny. 


\section{Discussion}

After that the condition of teaching learning is effective. The students response $77,1 \%$. It can be seen from their gesture which were comfortable sit in their chair and their eyes which are not be pointes to the teacher but to another thing in the class room.

On the country, in experimental class, during the learning process students gave more attentions than control class. It happened because using bilingual module was a kind of cooperative learning as school improvement, therefore if ford and involved student to be more active, then, it will give influence to the students in their score of their response $22,9 \%$.

The first implementation of bilingual module is teacher directed. In this case, the teacher served as the leader of the class, explaining the strategies and modeling students for others in the class. The teacher's task included modeling the strategies, monitoring students learning and understanding, scaffolding their effects, and providing students with feedback.

By bilingual module, the students are offered an effective comprehensionbuilding strategy that involves team effort and dialogue among lecturing and students. Therefore it can increase student's achievement and improve their score /result of test. It can be seen from the post test in experimental class.

\section{CONCLUSION}

Based on the results of the writers, the quantitative data showed that:

a. The means of two groups in posttest were significant. It was supported by the result of student's test the mean of the post-test of students at experimental class is 74.5. This result is higher than the mean of the post-test of students at control class that got 67.75 . This means that there is the difference score gained between the students that have been given the treatment

b. The alternative hypothesis is received

According to the result of calculation, it can be seen that $t_{\text {count }} \geq t_{\text {table }}$ or $2.3539 \geq 1,688$. It shows that the learning effectiveness of using bilingual module based toward student's achievement of learning is significant. In conclusion, the writers could conclude that the use bilingual module based effective and increase learning achievement 
for the students in thematic

learning.

\section{REFERENCES}

Baker, C. (2006). Foundations of Bilingual Education and Bilingualism. Clevedon, UK: Multilingual Matters

Brown, H. Douglas. (2001). Teaching by Principles: An Interactive Approach to

Language Pedagogy. New York: Addison Wesley Longman Inc. International Reading Association.

Gay, R. L, Mills E Geoffrey, and Airasan Peter. (2009), Educational Writers Competencies for Analysis and Applications, United State: Kevin M.Davis.
Kandolf, C. (1998). Myths about Bilingualism. Norway: Bilingual Families Web Page. Retrieved October 12, 2009, from http://www.nethelp.no/cindy/myth. html

Richards, Jack and Renandya, Willy. (2002). Methodology In Language Teaching. Cambridge University Press

Sugiyono, Prof. Dr . (2013).Metode Penelitian

Pendidikan,(pendekatanKuantitatif, Kualitatif, dan R\&D): Alfabeta Bandung. 